\title{
UJI ORGANOLEPTIK BUTTER COOKIES FORTIFIKASI KALSIUM DARI TULANG IKAN BELIDA (Chitala lopis)
}

\section{ORGANOLEPTIC TEST OF BUTTER COOKIES OF CALCIUM FORTIFICATION FROM BELIDA FISH BONE (Chitala lopis)}

\author{
Seftylia Diachanty ${ }^{1 \#}$, Indrati Kusumaningrum ${ }^{1}$, dan Andi Noor Asikin ${ }^{1}$ \\ ${ }^{1}$ Program Studi Teknologi Hasil Perikanan, FPIK, Universitas Mulawarman \\ Jalan Gunung Tabur, Kampus Gunung Kelua Samarinda, Indonesia \\ E-mail: seftylia@gmail.com
}

(Diterima: 13 Februari 2021; Diterima setelah perbaikan: 15 September 2021; Disetujui: 19 September 2021)

\begin{abstract}
ABSTRAK
Tulang ikan belida merupakan salah satu limbah hasil pengolahan ikan yang belum dimanfaatkan secara optimal. Komponen penyusun tulang ikan yang masih dapat dimanfaatkan adalah kalsium. Faktor utama pemenuhan mutu suatu produk adalah nilai organoleptik yang meliputi kriteria penilaian terhadap kenampakan, cita rasa, dan nilai gizi suatu produk. Penelitian ini bertujuan untuk mengetahui tingkat penerimaan konsumen melalui pengujian organoleptik terhadap butter cookies yang difortifikasi kalsium dari tepung tulang ikan belida. Parameter yang diamati pada penelitian ini adalah, cooking loss (CL), yield (Y), dan tingkat penerimaan panelis. Hasil penelitian menunjukkan bahwa nilai CL berkisar antara 9,0-10,1\% dan nilai Y berkisar antara 89,9-90,5\%. Kedua parameter tidak menunjukkan adanya perbedaan yang nyata antara perlakuan $(p>0,05)$. Hasil uji kesukaan panelis dilakukan dengan metode Kruskal Wallis menunjukkan ada perbedaan yang nyata pada parameter warna $(p<0,05)$. Nilai uji kesukaan panelis tidak berpengaruh nyata $(p>0,05)$ terhadap rasa, aroma dan tekstur. Berdasarkan hasil uji kesukaan, penambahan tepung tulang ikan belida hingga konsentrasi 6\% masih disukai panelis.
\end{abstract}

KATA KUNCI: butter cookies; hedonik; kalsium; tulang ikan

\begin{abstract}
Belida fish bone is one of the waste from fish processing that has not been used optimally. The constituent components of fish bones that can still be utilized is calcium. Main factor in fulfillment the quality of a product is the organoleptic value which includes the criteria for assessing the appearance, taste and nutritional value of a product. This study aims to determine the level of consumer acceptance through organoleptic testing of butter cookies fortified with calcium from belida fish bone flour. The parameters observed in this study were cooking loss (CL), yield (Y), and panelist acceptance level. The results showed that the $C L$ value ranged from 9.0 to $10.1 \%$ and the $Y$ value ranged from 89.9 to $90.5 \%$. Both parameters did not show any significant difference between treatments $(p>0.05)$. The panelist preference test results performed by the Kruskal Wallis method showed there was significant differences in the color parameters $(p<0.05)$. The panelist preference test value had no significant effect $(p>0.05)$ on taste, odor, and texture. Based on the consideration of panelists preference, the addition of fish bone meal up to 6\% is still preferred by panelists.
\end{abstract}

KEYWORDS: butter cookies; hedonic; calcium; fish bone

\footnotetext{
\# Korespondensi: Program Studi Teknologi Hasil Perikanan,

FPIK, Universitas Mulawarman

E-mail: seftylia@gmail.com
} 


\section{PENDAHULUAN}

Tulang ikan belida merupakan salah satu limbah dari usaha pengolahan amplang maupun kerupuk ikan yang ada di Kalimantan Timur. Tulang ikan selama ini belum dimanfaatkan secara optimal dan hanya dibuang saja. Menurut Amitha et al., (2019), limbah ikan yang tidak termanfaatkan dapat menimbulkan permasalahan baru seperti pencemaran lingkungan. Limbah ikan berupa tulang ikan sebenarnya masih dapat dimanfaatkan sebagai bahan baku produk hasil perikanan salah satunya sebagai tepung tulang.

Tepung tulang ikan (TTI) adalah suatu produk padat kering yang dihasilkan dengan cara mengeluarkan sebagian besar cairan dan sebagian atau seluruh lemak yang terkandung dalam tulang ikan. Tulang ikan dapat dijadikan salah satu sumber kalsium untuk pengayaan (enrichment) sebagai upaya fortifikasi zat gizi dalam makanan, karena memiliki kandungan kalsium terbanyak di antara bagian tubuh ikan. Unsur utama dari tulang ikan adalah kalsium, fosfor, karbonat (Trilaksani et al., 2006), magnesium, besi, dan zinc (Herpandi et al., 2019). Moemin (2015) menambahkan bahwa tulang ikan mengandung kalsium terutama kalsium fosfat dan sodium (Ananda \& Anggraeni, 2021). Putranto et al., (2015) menyatakan bahwa tepung tulang ikan belida mengandung kadar abu $88,13 \%$ dan kalsium 30,93\%, sedangkan Kusumaningrum et al., (2016) menyatakan, kisaran kadar kalsium pada tepung tulang ikan belida sebesar 28,25\%-31,31\% dan kadar fosfor berkisar 3,95\%-4,06\%.

Pemanfaatan tulang ikan sebagai fortifikasi pada makanan yang telah dilakukan antara lain penambahan tepung ikan gabus sebanyak $0 \%, 10 \%, 15 \%$ dan $20 \%$ pada pembuatan biskuit fungsional (Sari et al., 2014), fortifikasi tepung tulang ikan nila sebanyak $6 \%, 12 \%$, $18 \%$ dan $24 \%$ pada pembuatan cookies (Moemin, 2015), fortifikasi kalsium dari tepung tulang ikan belida $0 \%$, $5 \%, 10 \%, 15 \%$ dan $20 \%$ pada pembuatan kerupuk (Kusumaningrum \& Asikin, 2016). Salah satu alternatif pemanfaatan TTI yang lainnya yaitu dengan mengaplikasikan TTI sebagai fortifikasi kalsium pada biskuit/cookies. Cookies merupakan produk snack yang memiliki kandungan gula dan lemak yang tinggi, namun rendah dalam kandungan kalsium (Rahmawati $\&$ Nisa, 2015). Prospek pemanfaatan TTI dalam bentuk cookies mempunyai prospek yang cukup baik, mengingat proses pengolahan yang relatif mudah dan murah. Pemanfaatan TTI sebagai sumber kalsium pada produk pangan merupakan salah satu upaya diversifikasi produk dari tulang ikan, untuk mengatasi defisiensi kalsium dan alternatif dalam mengatasi limbah pengolahan hasil perikanan.

Faktor utama pemenuhan mutu suatu produk adalah nilai organoleptik yang meliputi kriteria penilaian terhadap kenampakan, cita rasa, dan nilai gizi suatu produk. Pengujian organoleptik bertujuan untuk melihat tingkat penerimaan konsumen terhadap suatu produk. Setyaningsih et al., (2010) menjelaskan bahwa tujuan analisa sensori adalah sebagai pengujian terhadap bahan makanan berdasarkan kesukaan dan kemauan untuk mempergunakan suatu produk. Sifat yang menentukan diterima atau tidak suatu produk adalah sifat indrawi. Berdasarkan hal tersebut, maka penelitian ini bertujuan untuk mengetahui tingkat penerimaan konsumen melalui pengujian organoleptik terhadap butter cookies yang difortifikasi kalsium dari TTI belida.

\section{BAHAN DAN METODE}

Bahan baku utama dalam pembuatan tepung tulang ikan (TTI) belida adalah tulang ikan belida (Chitala lopis) yang berasal dari limbah pengolahan amplang di Samarinda. Bahan tambahan yang digunakan dalam pembuatan butter cookies adalah tepung terigu rendah protein, tepung maizena, susu bubuk, gula halus, mentega, baking powder, kuning telur dan butter.

Alat yang digunakan terdiri dari panci bertekanan (presto), oven (merk Memmert), blender (merk Phillips), oven elektrik (merk Maspion), mixer (merk Phillips), loyang, ayakan tepung, dan spatula.

Penelitian ini terdiri dari dua tahap. Tahap pertama terdiri dari pembuatan tepung tulang ikan belida (Kusumaningrum et al., 2016). Pembuatan tepung tulang ikan belida dimulai dengan membersihkan tulang ikan dari kotoran menggunakan air mengalir. Tulang direbus pada suhu $80^{\circ} \mathrm{C}$ selama 30 menit. Tulang yang telah direbus kemudian dicuci kembali menggunakan air mengalir dan dilanjutkan dengan proses pelunakan tulang (presto) selama 3 jam dan dilanjutkan dengan proses perebusan sebanyak 4 kali dengan lama waktu perebusan masing-masing adalah 30 menit. Setelah proses perebusan selesai, dilanjutkan dengan proses perendaman tulang di dalam larutan $\mathrm{NaOH} 1,5 \mathrm{~N}$ selama 2 jam pada suhu $60^{\circ} \mathrm{C}$, yang dilanjutkan dengan pengeringan tulang menggunakan oven dengan suhu $65^{\circ} \mathrm{C}$ selama $48 \mathrm{jam}$. Tulang yang sudah kering dihaluskan menggunakan blender hingga berbentuk tepung dan dilanjutkan dengan tahap pembuatan butter cookies.

Tahap kedua terdiri dari proses pembuatan butter cookies yang mengacu pada Moemin (2015) yang dimodifikasi. Proses pembuatan butter cookies terdiri dari beberapa tahapan di antaranya persiapan bahan, penimbangan bahan, pembuatan adonan, pencetakan adonan dan pengovenan. Bahan-bahan pembuatan butter cookies meliputi tepung terigu, tepung maizena dan susu bubuk disiapkan terlebih dahulu, kemudian diayak menggunakan ayakan berukuran 100 mesh agar 
diperoleh keseragaman ukuran. Tahapan selanjutnya, bahan tambahan lain seperti mentega, butter, telur dan gula halus dikocok menggunakan mixer hingga homogen dan kental. Selanjutnya, adonan yang telah homogen dan bahan kering (tepung terigu, tepung maizena dan susu bubuk) dicampur, kemudian ditambahkan tepung tulang sesuai dengan perlakuan dan diaduk hingga kalis. Adonan yang sudah kalis kemudian dicetak dan dioven hingga matang pada suhu pemanggangan di oven $160{ }^{\circ} \mathrm{C}$ selama 20 menit. Parameter yang diamati pada penelitian ini adalah cooking loss $(\mathrm{CL})$, yield $(\mathrm{Y})$, dan tingkat penerimaan panelis.

Penelitian ini menggunakan Rancangan Acak Lengkap (RAL) dengan satu faktor yang terdiri dari 7 taraf perlakuan konsentrasi tepung tulang ikan yaitu $0 \%, 2 \%, 4 \%, 6 \%, 8 \%, 10 \%$ dan $12 \%$ dari berat tepung yang digunakan. Pengujian penerimaan terhadap butter cookies menggunakan uji organoleptik berupa uji hedonik sebanyak 30 panelis. Parameter organoleptik yang digunakan meliputi warna, rasa, tekstur dan aroma dengan menggunakan skala hedonik (skala 1: sangat tidak suka, 2: tidak suka, 3: netral, 4: suka, 5: sangat suka) untuk melakukan tingkat kesukaan panelis. Perhitungan uji organoleptik dilakukan menggunakan analisis non parametrik yaitu uji Kruskal Wallis.

\section{HASIL DAN BAHASAN}

\section{Cooking Loss (CL)}

Pembuatan butter cookies pada penelitian ini dilakukan dengan menambahkan TTI belida dengan beberapa konsentrasi yang berbeda sebagai sumber kalsium alami. Hasil yang diperoleh dibandingkan dengan tanpa penambahan TTI belida. Cooking Loss $(C L)$ selama pemanggangan dihitung berdasarkan berat adonan sebelum dipanggang dikurangi berat butter cookies setelah matang dibandingkan dengan berat adonan awal dikali 100 (Murugkar et al.,2018). Nilai cooking loss butter cookies yang ditambahkan tepung tulang ikan belida dapat dilihat pada Tabel 1 .

Tabel 1. Nilai cooking loss butter cookies fortified

Table 1. Cooking loss of fortified butter cookies

\begin{tabular}{cccr}
\hline Perlakuan & Adonan $(\mathrm{g})$ & Cooking $(\mathrm{g})$ & $C L(\%)$ \\
\hline $\mathrm{P}_{0}$ & 235,33 & 211,67 & $10,06^{\mathrm{a}}$ \\
$\mathrm{P}_{2}$ & 237,33 & 216,00 & $9,01^{\text {a }}$ \\
$\mathrm{P}_{4}$ & 249,67 & 225,00 & $9,93^{\text {a }}$ \\
$\mathrm{P}_{6}$ & 253,00 & 229,00 & $9,52^{\text {a }}$ \\
$\mathrm{P}_{8}$ & 254,00 & 226,00 & $11,09^{\text {a }}$ \\
$\mathrm{P}_{10}$ & 255,33 & 228,67 & $10,47^{\text {a }}$ \\
$\mathrm{P}_{12}$ & 258,33 & 229,33 & $11,22^{\text {a }}$ \\
\hline Keterangan: CL: Cooking Loss & &
\end{tabular}

Berdasarkan hasil analisis sidik ragam diperoleh bahwa cooking loss butter cookies tulang ikan belida tidak berbeda nyata terhadap perlakuan $\mathrm{P}_{0}(0 \%), \mathrm{P}_{2}(2 \%)$,
$\mathrm{P}_{4}(4 \%), \mathrm{P}_{6}(6 \%), \mathrm{P}_{8}(8 \%), \mathrm{P}_{10}(10 \%)$ dan $\mathrm{P}_{12}(12 \%)(p>$ $0,05)$. Cooking loss butter cookies tulang ikan belida, berkisar 9,01-11,22\%. Nilai cooking loss tertinggi pada perlakuan $\mathrm{P}_{12}(12 \%)$ adalah $11,22 \%$. Hal ini menunjukkan bahwa semakin tinggi konsentrasi tepung ikan belida yang ditambahkan, maka nilai cooking loss butter cookies semakin tinggi. Pratama dan Nisa (2014) menyatakan jika nilai cooking loss meningkat, hal tersebut dikarenakan kandungan gluten yang ada pada tepung terigu menurun. Gluten mempunyai kemampuan untuk membentuk jaringan tiga dimensi yang dapat menghambat keluarnya isi granula pada bahan. Pernyataan tersebut didukung oleh Dewantara et al., (2019) yang menyatakan bahwa apabila nilai cooking loss semakin tinggi, maka kandungan pati yang lepas semakin banyak. Hal tersebut diduga karena pati tidak tergelatinisasi sempurna antara tepung tulang ikan dengan tepung terigu.

\section{Rendemen}

Nilai rendemen butter cookies menunjukkan perbandingan berat adonan matang dengan berat adonan awal dikalikan 100. Nilai rendemen butter cookies yang ditambahkan TTI belida berkisar 88,78 $90,99 \%$. Hal ini dapat dipengaruhi oleh lamanya pemanggangan. Semakin lama proses pemanggangan, kadar air pada adonan semakin berkurang sehingga rendemen yang dihasilkan semakin rendah. Nilai rendemen butter cookies fortified dapat dilihat pada Tabel 2.

Tabel 2. Rendemen butter cookies fortified

\section{Table 2. Yield of fortified butter cookies}

\begin{tabular}{cc}
\hline Perlakuan & Rendemen (\%) \\
\hline $\mathrm{P}_{0}$ & $89,94^{\mathrm{a}}$ \\
$\mathrm{P}_{2}$ & $90,99^{\mathrm{a}}$ \\
$\mathrm{P}_{4}$ & $90,07^{\mathrm{a}}$ \\
$\mathrm{P}_{6}$ & $90,48^{\mathrm{a}}$ \\
$\mathrm{P}_{8}$ & $88,91^{\mathrm{a}}$ \\
$\mathrm{P}_{10}$ & $89,53^{\mathrm{a}}$ \\
$\mathrm{P}_{12}$ & $88,78^{\mathrm{a}}$ \\
\hline
\end{tabular}

Berdasarkan analisis sidik ragam, rendemen butter cookies tulang ikan belida tidak berbeda nyata terhadap perlakuan $\mathrm{P}_{0}(0 \%), \mathrm{P}_{2}(2 \%), \mathrm{P}_{4}(4 \%), \mathrm{P}_{6}(6 \%), \mathrm{P}_{8}$ (8\%), $P_{10}(10 \%)$ dan $P_{12}(12 \%)(p>0,05)$. Rahmaningsih et al., (2016) menyatakan bahwa selama proses pemanggangan biskuit/cookies ikan banyak air yang terevaporasi dari adonan. Proses pemanggangan juga menyebabkan hilangnya kadar air dari permukaan biskuit/cookies karena terevaporasi yang diikuti oleh perpindahan kelembaban ke permukaan yang terusmenerus hilang ke sekitar oven. Pernyataan tersebut di dukung oleh Mervina et al.,(2012) yang menyatakan bahwa penurunan nilai rendemen pada pembuatan biskuit/cookies dapat disebabkan oleh adanya kehilangan bahan selama proses pengolahan. 


\section{Karakteristik Butter Cookies Tulang Ikan Belida}

\section{Warna}

Penambahan tepung tulang ikan belida pada pembuatan butter cookies menghasilkan warna cokelat agak gelap dibandingkan dengan butter cookies yang tidak diberi tambahan TTI belida. Hal ini dikarenakan adanya reaksi Maillard yang terjadi pada saat proses pengolahan. Menurut Cicilia et al. (2018), reaksi Maillard yang terjadi pada saat proses pemanggangan adonan, di mana gula pereduksi bereaksi dengan senyawa yang memiliki gugus $\mathrm{NH}_{2}$ (protein, asam amino dan peptida). Reaksi ini akan terjadi apabila bahan pangan dipanaskan dan ketika gula pereduksi bereaksi dengan sebuah gugus amina primer/sekunder akan membentuk suatu glukosamin. Komponen tersebut selanjutnya akan membentuk komponen berwarna gelap melanoidin yang menyebabkan perubahan warna pada bahan pangan. Grafik pengaruh penambahan tepung tulang ikan belida terhadap warna butter cookies dapat dilihat pada Gambar 1.
Berdasarkan uji hedonik dan analisis menggunakan Kruskal-Wallis, penambahan TTI dengan konsentrasi tertentu berpengaruh nyata $(p<0,05)$ terhadap warna dari butter cookies. Berdasarkan Gambar 1, butter cookies yang ditambahkan TTI belida lebih disukai oleh para panelis $(3,88-4,52)$, jika dibandingkan dengan kontrol (TTI 0\%). Hal ini dikarenakan warna yang dihasilkan pada butter cookies dengan perlakuan kontrol lebih pucat dibandingkan dengan butter cookies yang diberi perlakuan (TTI 2\%; TTI 4\%; TTI 6\%; TTI $8 \%$; TTI 10\%; TTI 12\%). Menurut Seveline et al., (2019) warna adalah salah satu bagian dari penampakan produk dan merupakan salah satu parameter penilaian sensori yang penting karena merupakan penilaian sensori yang dilihat atau dinilai pertama kali oleh konsumen.

\section{Tekstur}

Tekstur merupakan salah satu parameter penilaian sensori yang perlu diperhatikan dalam produk cookies dan biskuit. Kerenyahan suatu cookies dapat diukur dengan cara mudah atau tidaknya cookies tersebut hancur ketika digigit (Seveline et al.,2019). Berdasarkan hasil uji hedonik dan analisis

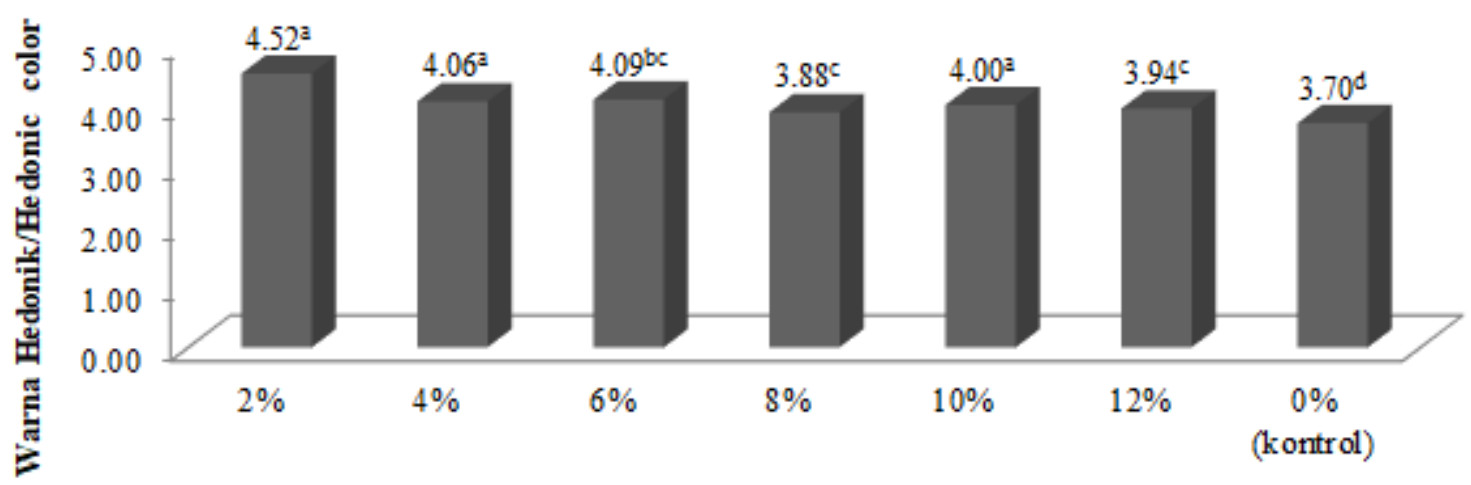

Konsentrasi Tepung Tulang Ikan Belida/Concentration of Belida Fish Bone Flour

Gambar 1. Pengaruh penambahan tepung tulang ikan belida terhadap warna butter cookies Figure 1. Fortification's effect of belida fish bone flour on the color of butter cookies

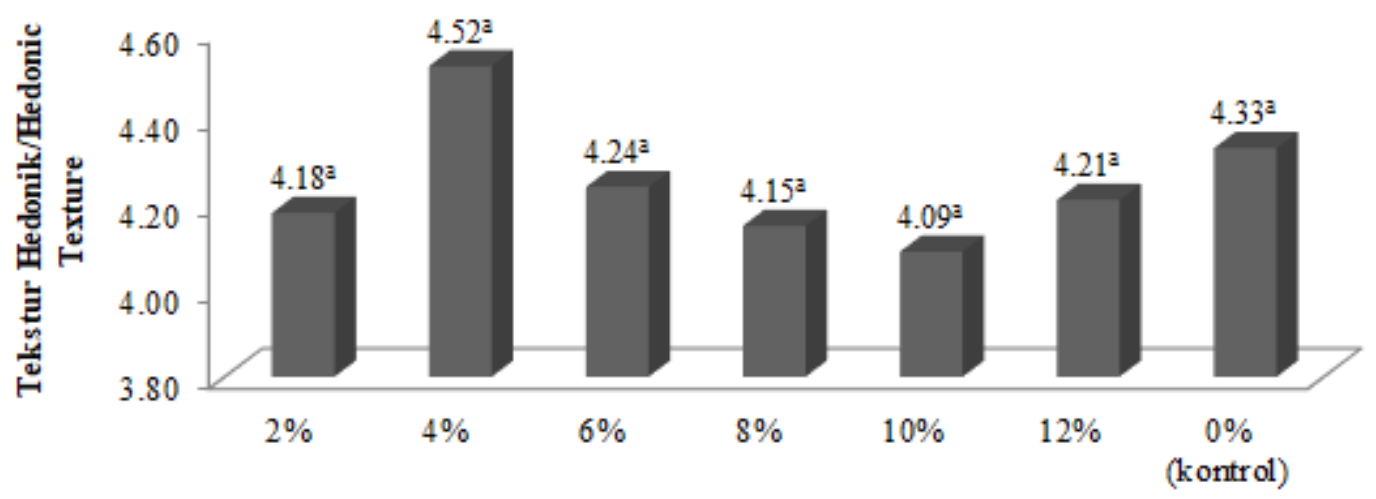

Konsentrasi Tepung Tulang Ikan Belida/Concentration of Belida Fish Bone Flour

Gambar 2. Pengaruh penambahan tepung tulang ikan belida terhadap tekstur butter cookies Figure 2. Fortification's effect of belida fish bone flour on the texture of butter cookies 


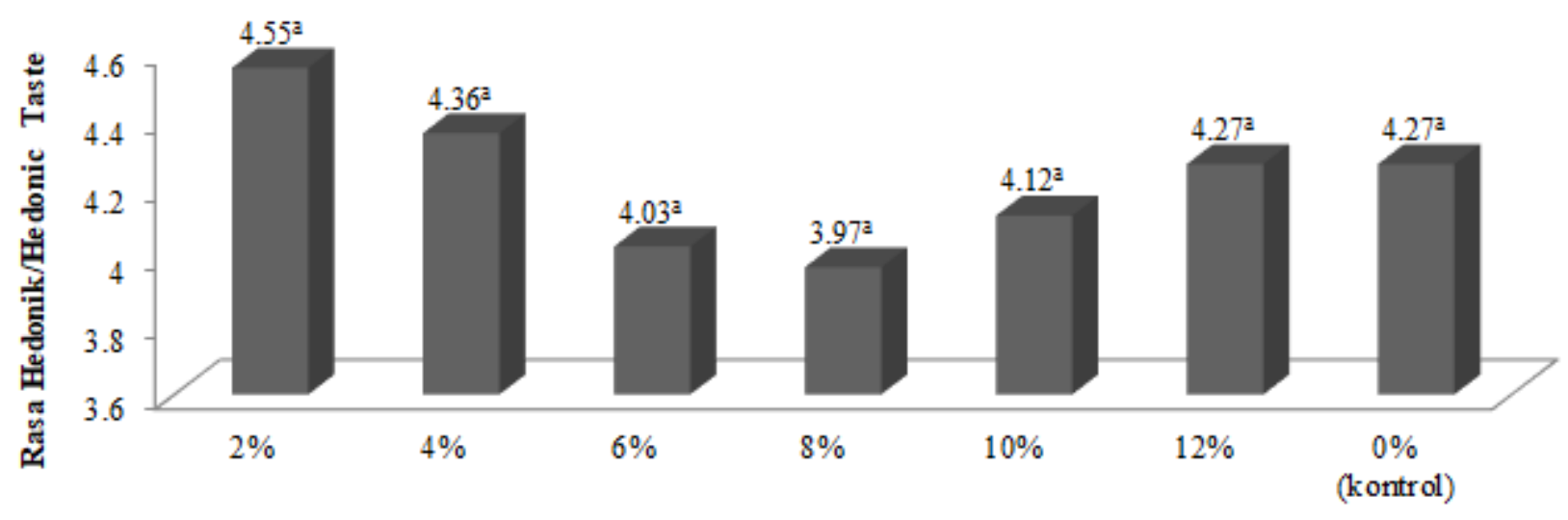

Konsentrasi Tepung Tulang Ikan Belida/Concentration of Belida Fish Bone Flour

Gambar 3. Pengaruh penambahan tepung tulang ikan belida terhadap rasa butter cookies Figure 3. Fortification's effect of belida fish bone flour on the flavor of butter cookies

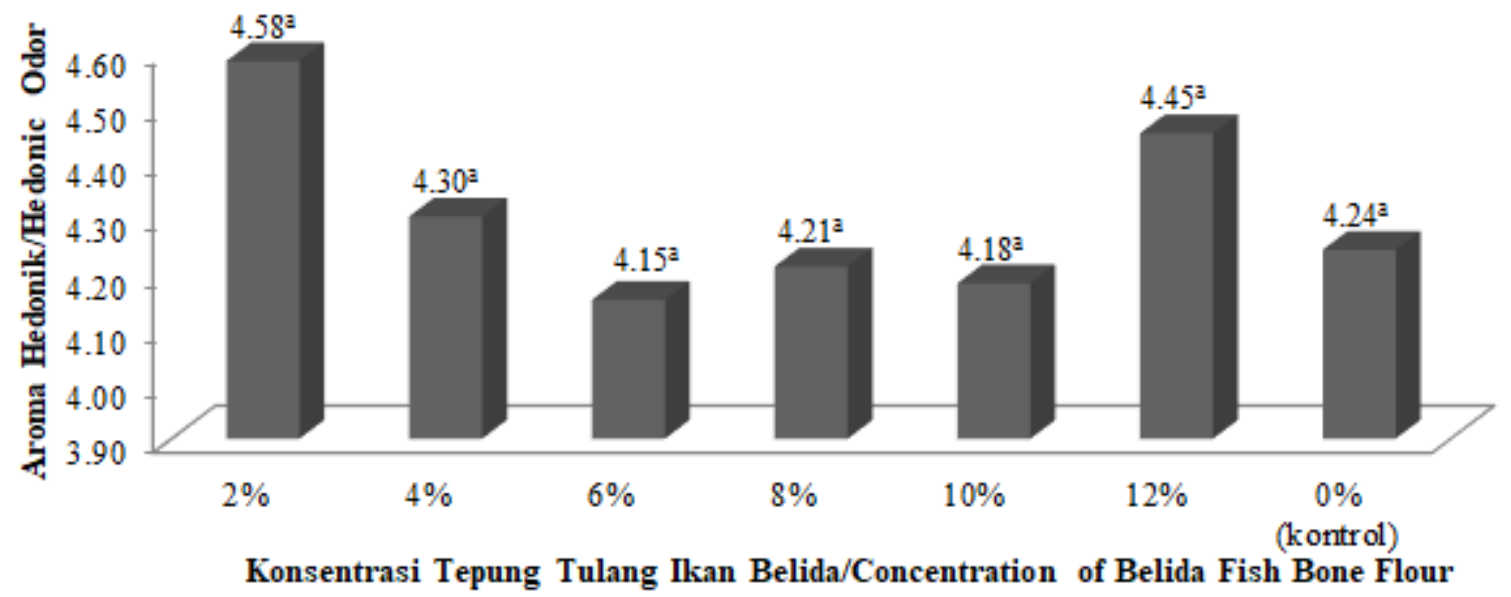

Gambar 4. Pengaruh penambahan tepung tulang ikan belida terhadap bau butter cookies

Figure 4. Fortification's effect of belida fish bone flour on the odor of butter cookies

menggunakan Kruskal-Wallis, penambahan TTI dengan konsentrasi tertentu tidak berpengaruh nyata $(p>0,05)$ terhadap tekstur dari butter cookies. Butter cookies yang ditambahkan TTI belida menghasilkan tekstur yang disukai oleh panelis $(4,09-4,52)$, khususnya pada perlakuan TTI 4\%. Menurut Ernisti et al., (2018), kriteria mutu sensori biskuit dan cookies untuk penilaian tekstur yaitu biskuit/cookies sebaiknya renyah dan lembut. Nadimin et al., (2019) menambahkan bahwa tekstur merupakan atribut penilaian yang mempengaruhi penerimaan panelis terhadap daya terima. Tekstur memiliki sifat yang kompleks dan dengan struktur bahan yang terdiri dari tiga elemen yaitu mekanik (kekerasan, kekenyalan), geometrik (berpasir, beremah), dan mouthfeel (berminyak, berair). Grafik pengaruh penambahan tepung tulang ikan belida terhadap tekstur butter cookies dapat dilihat pada Gambar 2.

\section{Rasa}

Berdasarkan hasil uji hedonik dan analisis menggunakan Kruskal-Wallis (Gambar 3), penambahan
TTI dengan konsentrasi tertentu tidak berpengaruh nyata $(p>0,05)$ terhadap rasa dari butter cookies. Butter cookies yang ditambahkan TTI belida berkisar 3,97-4,55 (disukai). Rasa butter cookies yang disukai oleh panelis dengan perlakuan konsentrasi TTI belida $2 \%$. Hal tersebut dikarenakan rasa ikan yang ada pada butter cookies tidak terlalu berasa dibandingkan dengan kontrol dan konsentrasi yang lain. Nastiti dan Christyaningsih (2019) menyatakan bahwa penambahan tepung ikan pada biskuit atau cookies akan mempengaruhi rasa dari biskuit atau cookies.

Menurut Cicilia et al., (2018), rasa suatu bahan pangan dapat dipengaruhi oleh beberapa faktor yaitu senyawa kimia, temperatur, dan interaksi dengan komponen rasa yang lain. Seveline et al., (2019) menambahkan, rasa berasal dari perpaduan bahan pembentuk dan komposisi pada suatu produk makanan yang ditangkap oleh indera pengecap. Penilaian terhadap rasa melibatkan indera lidah, sehingga rasa enak dapat menarik perhatian konsumen untuk cenderung menyukai makanan dari rasa. 


\section{Aroma}

Aroma adalah bau yang ditimbulkan oleh rangsangan kimia yang tercium oleh syaraf-syaraf olfaktori yang berada di dalam rongga hidung ketika makanan masuk ke dalam mulut (Nadimin et al., 2019). Berdasarkan hasil uji hedonik dan analisis menggunakan KruskalWallis (Gambar 4), penambahan TTI dengan konsentrasi tertentu tidak berpengaruh yang nyata $(p>0,05)$ terhadap aroma dari butter cookies. Butter cookies TTI belida menghasilkan aroma yang secara keseluruhan disukai oleh panelis $(4,15-4,58)$. Butter cookies dengan penambahan TTI $2 \%$ sangat disukai oleh panelis dibandingkan dengan konsentrasi yang lain. Hal ini dapat disebabkan karena sedikitnya konsentrasi TTI belida yang ditambahkan dibandingkan dengan perlakuan lainnya (kecuali kontrol), sehingga lebih sedikit tercium aroma amis dari TTI belida. Menurut Seveline et al., (2019), semakin tinggi substitusi tepung yang digunakan maka rata-rata pada indikator aroma khas bahan yang digunakan akan semakin tinggi.

Rahmawati dan Rustanti (2013) menyatakan bahwa cookies yang disubstitusi tepung tempe dan tepung teri menimbulkan aroma yang langu dan amis. Aroma amis merupakan aroma khas pada ikan yang disebabkan oleh komponen nitrogen yaitu guanidine, trimetil amin oksida (TMAO) dan turunan imidazol. Hal ini juga didukung oleh Nadimin et al., (2019), yang menambahkan tepung ikan kembung pada pembuatan cookies, pada hasil uji organoleptik adanya penambahan tepung ikan kembung cenderung menghasilkan aroma amis pada cookies. Aroma tersebut terdeteksi ketika zat yang mudah menguap diterima oleh indera penciuman.

\section{KESIMPULAN}

Butter cookies yang difortifikasi kalsium dari TTI belida memiliki nilai CL berkisar antara 9,0-10,1\% dan nilai Y berkisar antara 89,9-90,5\% dan tidak menunjukkan adanya perbedaan yang nyata antar perlakuan $(p>0,05)$. Hasil uji kesukaan panelis dilakukan dengan metode Kruskal Wallis menunjukkan ada perbedaan yang nyata $(p<0,05)$ pada parameter warna dan tidak berpengaruh nyata $(p>0,05)$ terhadap rasa, aroma dan tekstur serta dapat diterima oleh panelis hingga konsentrasi 6\%. Penambahan TTI belida pada butter cookies dapat dijadikan sebagai salah satu alternatif nutrisi tambahan yang bermanfaat bagi tubuh.

\section{UCAPAN TERIMA KASIH}

Penulis mengucapkan terima kasih kepada Fakultas Perikanan dan Ilmu Kelautan Universitas Mulawarman yang telah memberikan dana bantuan penelitian.

\section{DAFTAR PUSTAKA}

Amitha, Raju, C., Lakshmisha, I., Kumar, A. P., Sarojini, A., \& Gajendra. Pal, J. (2019). Nutritional Composition of Fish Bone Powder Extracted from Three Different Fish Filleting Waste Boiling with Water and Alkaline Media. International Journal of Current Microbiology and Applied Science, 8 (2), 29422948.

Ananda, S., \& Anggraeni, A. (2021). Substitution of Fishbone Powder in the Development of Choco Chips Cookies. The 3rd International Conference on Food and Agriculture.672, pp. 1-7. Orlando, Florida: IOP Conference Series: Earth and Environmental Science.

Cicilia, S., Basuki, E., Prarudiyanto, A., Alamsyah, A., \& Handito, D. (2018). Pengaruh Substitusi Tepung Terigu dengan Tepung Kentang Hitam (Coleus tuberosus) terhadap Sifat Kimia dan Organoleptik Cookies. Jurnal IImu dan Teknologi Pangan, 4 (1), 304-310.

Dewantara, E. C., Wijayanti, I., \& Anggo, A. D. (2019). Karakteristik Fisiko Kimia dan Sensori Pasta Makaroni dengan Penambahan Tepung Ikan Gabus (Channa striata). Jurnal Ilmu dan Teknologi Perikanan, 1 (2), 22-29.

Ernisti, W., Riyad, S., \& Jaya, F. M. (2018). Karakteristik Biskuit (Crackers) yang Difortifikasi dengan Konsentrasi Penambahan Tepung Ikan Patin Siam (Pangasius hypophthalmus) Berbeda. Jurnal IImuIImu Perikanan dan Budidaya Perairan, 13 (2), 88100.

Herpandi, Widiastuti, I., Wulandari, \& Sari, C. A. (2019). Efektivitas Natrium Bikarbonat (NaHCO3) terhadap Karakteristik Fisikokimia dan Sensori Keripik Tulang Ikan Putak (Notopterus notopterus). Jurnal Pengolahan Hasil Perikanan Indonesia, 22 (2), 263-272.

Kusumaningrum, I., \& Asikin, A. N. (2016). Karakteristik Kerupuk Ikan Fortifikasi Kalsium dari Tulang Ikan Belida. Jurnal Pengolahan Hasil Perikanan Indonesia , 19 (3), 233-240.

Kusumaningrum, I., Sutono, D., \& Pamungkas, B. F. (2016). Pemanfaatan Tulang Ikan Belida sebagai Tepung Sumber Kalsium dengan Metode Alkali. Jurnal Pengolahan Hasil Perikanan Indonesia, 19 (2), 148-155.

Mervina, Kusharto, C. M., \& Marliyati, S. A. (2012). Formulasi Biskuit dengan Substitusi Tepung Ikan Lele Dumbo (Clarias gariepinus) dan Isolat Protein Kedelai (Glycine max) sebagai Makanan Potensial untuk Anak Balita Gizi Kurang. Jurnal Teknologi dan Industri Pangan, 23 (1), 9-16.

Moemin, A. A. (2015). Healthy Cookies from Cooked 
Fish Bones. Food Bioscience, 12, 114-121.

Murugkar, D. A., Dwivedi, S., Bajpai, P. D., \& Kumar, M. (2018). Effect of Natural Fortification with Calcium and Protein Rich Ingredients on Texture, Nutritional Quality and Sensory Acceptance of Cookies. Nutrition and Food Science, 48 (12), 2-14.

Nadimin, Sirajuddin, \& Fitriani, N. (2019). Mutu Organoleptik Cookies dengan Penambahan Tepung Bekatul dan Ikan Kembung. Media Gizi Pangan, 26 (1), 8-15.

Nastiti, A. N., \& Christyaningsih, J. (2019). Pengaruh Substitusi Tepung Ikan Lele terhadap Pembuatan Cooikes Bebas Gluten dan Kasein sebagai Alternatif Jajanan Anak Autism Spectrum Disorder. Media Gizi Indonesia, 14 (1), 35-43.

Pratama, I. A., \& Nisa, F. C. (2014). Formulasi Mie Kering dengan Substitusi Tepung Kimpul (Xanthosoma sagittifolium) dan Penambahan Tepung Kacang Hijau (Phaseolus radiatus L.). Jurnal Pangan dan Agroindustri, 2 (4), 101-112.

Putranto, H. F., Asikin, A. N., \& Kusumaningrum, I. (2015). Karakterisasi Tepung Tulang Ikan Belida (Chitala sp.) sebagai Sumber Kalsium dengan Metode Hidrolisis. Ziraa'ah, 40 (1), 11-20.

Rahmaningsih, A., Surti, T., \& Anggo, A. D. (2016). Pengaruh Penambahan Tepung Buah Lindur (Bruguiera gymnorrhiza) terhadap Kualitas Biskuit Ikan Lele (Clarias batrachus). Jurnal Pengolahan dan Bioteknologi Hasil Perikanan, 5 (3), 52-59.
Rahmawati, H., \& Rustanti, N. (2013). Pengaruh Substitusi Tepung Tempe dan Ikan Teri Nasi (Stolephorus sp.) terhadap Kandungan Protein, Kalsium, dan Organoleptik Cookies. Journal of Nutrition College, 2 (3), 382-390.

Rahmawati, W. A., \& Nisa, F. C. (2015). Fortifikasi Kalsium Cangkang Telur pada Pembuatan Cookies (Kajian Konsentrasi Tepung Cangkang Telur dan Baking Powder). Jurnal Pangan dan Agroindustri, 3 (3), 1050-1061.

Sari, D. K., Marliyati, S. A., Kustiyah, L., Khomsan, A., \& Gantohe, T. M. (2014). Uji Organoleptik Formulasi Biskuit Fungsional Berbasis Tepung Ikan Gabus (Ophiocephalus striatus). Agritech, 34 (2), 120-125.

Setyaningsih, D., Apriyantono, A., \& Sari, M. (2010). Analisis Sensori untuk Industri Pangan dan Agro. Bogor: IPB Press.

Seveline, Diana, N., \& Taufik, M. (2019). Formulasi Cookies dengan Fortifikasi Tepung Tempe dengan Penambahan Rosela (Hibiscus sabdariffa L.). Jurnal Bioindustri, 1 (2), 245-260.

Trilaksani, W., Salamah, E., \& Nabil, M. (2006). Pemanfaatan Limbah Tulang Ikan Tuna (Thunnus sp.) sebagai Sumber Kalsium dengan Metode Hidrolisis Protein. Buletin Teknologi Hasil Perikanan, 9 (2), 34-45. 